\title{
Retraction: screening and identification of a renal carcinoma specific peptide from a phage display peptide library
}

\author{
Xiangan $\mathrm{Tu}^{{ }^{1 * \dagger}}$, Jintao Zhuang ${ }^{1 \dagger}$, Wenwei Wang ${ }^{1}$, Liang Zhao ${ }^{1}$, Liangyun Zhao ${ }^{1}$, Jiquan Zhao ${ }^{1}$, Chunhua Deng ${ }^{1}$, \\ Shaopeng Qiu' ${ }^{1}$ and Yuanyuan Zhang ${ }^{2^{*}}$
}

\section{Retraction}

The authors would like to retract the article "Screening and Identification of a Renal Carcinoma Specific Peptide from a Phage Display Peptide Library" [1]. After the article was published it was revealed that the data in figure three, reported to show the Immunohistochemical staining of renal carcinoma, actually shows the results from an unrelated experiment on lung tissue due to incorrect labeling. The authors apologize to the readers, reviewers, and editors for publishing this erroneous data.

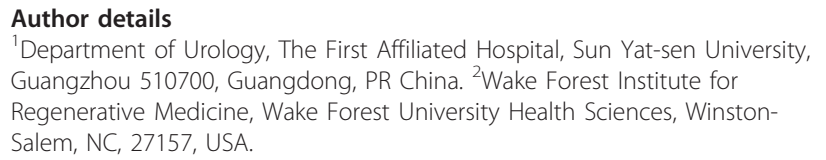

\section{Reference}

1. Tu X, Zhuang J, Wang W, Zhao L, Zhao L, Zhao J, Deng C, Qiu S, Zhang Y: Screening and Identification of a Renal Carcinoma Specific Peptide from a Phage Display Peptide Library. J Exp Clin Cancer Res 2011, 30:105.

\footnotetext{
* Correspondence: txabs9988@163.com; yzhang@wfubmc.edu

+ Contributed equally

'Department of Urology, The First Affiliated Hospital, Sun Yat-sen University, Guangzhou 510700, Guangdong, PR China

${ }^{2}$ Wake Forest Institute for Regenerative Medicine, Wake Forest University

Health Sciences, Winston-Salem, NC, 27157, USA

Full list of author information is available at the end of the article
}

Submit your next manuscript to BioMed Central and take full advantage of:

- Convenient online submission

- Thorough peer review

- No space constraints or color figure charges

- Immediate publication on acceptance

- Inclusion in PubMed, CAS, Scopus and Google Scholar

- Research which is freely available for redistribution 